\title{
Reproductive Ecology of Two Faviid Corals (Coelenterata: Scleractinia)
}

\author{
Barbara L. Kojis* and Norman J. Quinn* \\ Zoology Department, University of Queensland, Saint Lucia, Queensland 4067, Australia
}

\begin{abstract}
In common with other Faviidae, Favites abdita and Leptoria phrygia on Heron Island reef, Great Barrier Reef, Australia, are simultaneous hermaphrodites with ovary and testis in the same mesentery. During the annual gametogenic cycle oogenesis precedes spemiogenesis by several months. Both species exhibit synchronous spawning; gonads are released intermingled in positively buoyant compact spheres. Because of this it is believed that external self- and cross-fertilization occur in these species. Both species are present, but not abundant, in shallow and deeper water on the reef. Their mode and timing of spawning may largely confine propagule dispersal to the home reef, but not to any specific habitat within the reef. It is suggested that the release of eggs and sperm may be the commonest method of sexual reproduction in Scleractinia.
\end{abstract}

\section{INTRODUCTION}

Studies of reproduction in hermatypic corals have concentrated on planula releasing species (Stimson, 1978; Rinkevich and Loya, 1979a, b). As a result, the total variety of modes of sexual reproduction, both inter-and intra-taxon, is largely unknown. A study of reproduction in Goniastrea cf. favulus (= australensis) (Kojis and Quinn, 1981) confirmed that at least some hermatypic corals release eggs and sperm (Connell, 1973; Stimson, 1978). This led to the following questions about faviids: (1) Is a brief, annual spawning period common? (2) Are there variations in the mode and timing of gamete release? (3) If so, are they correlated with variations among species of within reef distribution and/or abundance?

To answer these questions the mode and timing of sexual reproduction, within reef distribution and abundance of 2 species of Faviidae, Favites abdita (Ellis and Solander, 1786) and Leptoria phrygia (Ellis and Solander, 1786) (nomenclature of Faviidae in accordance with Veron et al., 1977) were studied and compared to other Faviidae.

\footnotetext{
- Present address: Department of Fisheries Technology, Papua New Guinea University of Technology, P. O. Box 793, Lae, Papua New Guinea
}

\section{MATERIALS AND METHODS}

Sexual reproduction in Favites abdita and Leptoria phrygia was studied between January and December 1979 on Heron Island reef $\left(23^{\circ} 27^{\prime}\right.$ S), Great Barrier Reef, Australia. Here they form massive or encrusting colonies with a maximum diameter of approximately $60 \mathrm{~cm}$. Plastic tags were attached to 5 colonies of each species ( $>30 \mathrm{~cm}$ in diameter) with monofilament line. Samples $\left(>2 \mathrm{~cm}^{2}\right.$ in diameter) were chiseled at least every second month from each tagged colony and periodically from untagged colonies. We fixed the samples in $10 \%$ seawater formalin and $24 \mathrm{~h}$ later transferred them to a fresh solution for storage. Mesenteries were dissected from polyp samples, squashed on a slide, and observed using a binocular dissecting or high power microscope. Mature eggs could be seen in the field with the unaided eye.

Analysis of samples showed that gonads matured toward spring as in Goniastrea cf. favulus (Kojis and Quinn, 1981). Colonies were placed in aquaria in November/December and observed several times a day for spawning. Colonies in aquaria were replaced approximately every $2 \mathrm{wk}$ until spawning occurred. We measured spawned eggs on 2 perpendicular diameters using an ocular micrometer. Preserved gonad spheres were embedded in 'Tissue Prep', sec- 
tioned at a nominal thickness of $8 \mu \mathrm{m}$, and stained with Mayer's hematoxylin and eosin.

Distribution and abundance of Favites abdita and Leptoria phrygia on the reef flat were determined from 5 transects aligned perpendicular to the beach. All coral colonies $10 \mathrm{~cm}$ either side of a transect line were identified to genus or species and the distance each colony paralleled the line was measured (see Kojis and Quinn, 1981 for figure). Using SCUBA, we made casual observations of the presence and relative abundance of these species on the reef slope.

\section{RESULTS}

Favites abdita and Leptoria phrygia are simultaneous hermaphrodites with eggs and sperm clusters intermingled in the same mesentery. During the
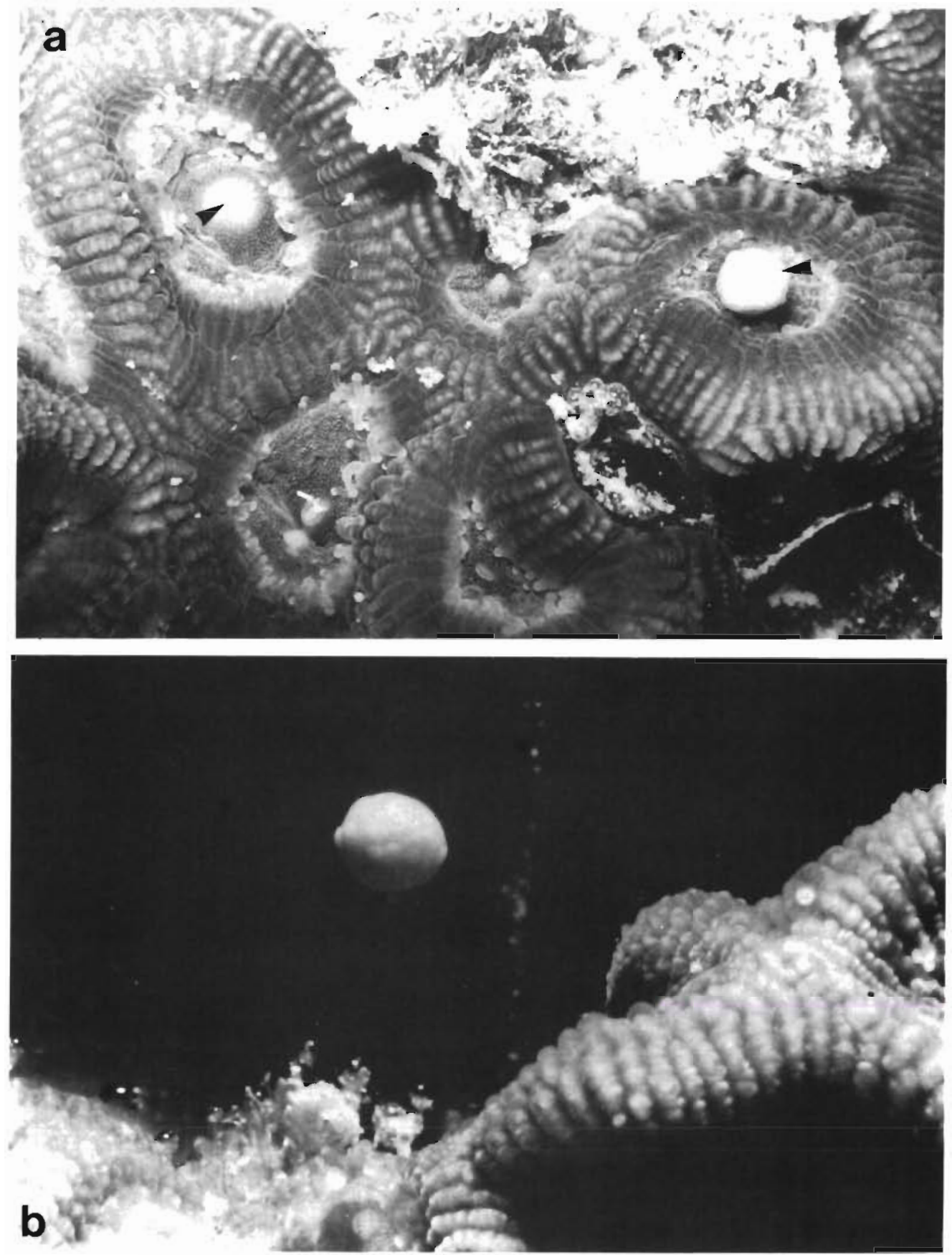

Fig. 1. Favites abdita.(a) Spheres composed of ova and sperm clusters being released. Sphere is in mouth of polyp at left; from polyp on right the sphere has just been released (arrows). (b) Positively buoyant sphere rising to the surface 
Fig. 2. Favites abdita. Histological section showing sperm clusters and ova. Note: germinal vesicle and zooxanthellae are absent. SC sperm clusters; O ova

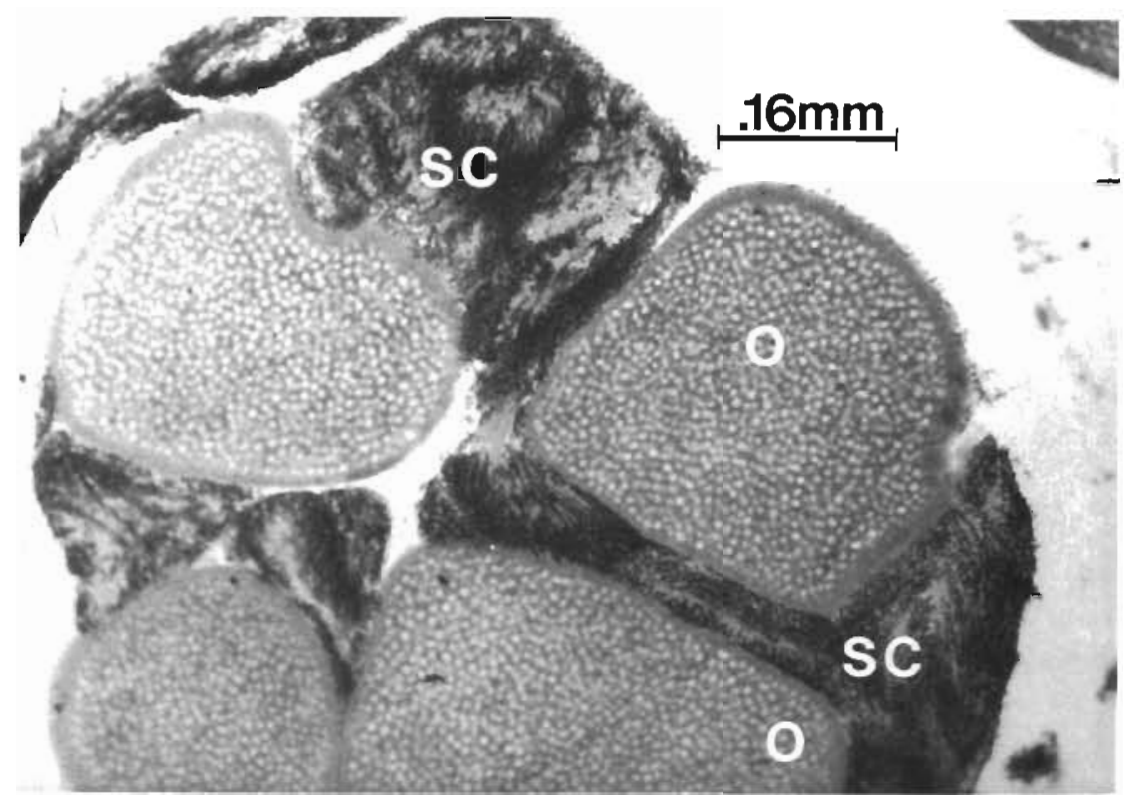

annual gametogenic cycle, oogenesis begins several months prior to spermiogenesis. Egg development began in April/May in F. abdita and in May/June in $L$. phrygia, while sperm development did not commence until late September/October.

Egg and sperm release is synchronous and seasonal. Both species spawned in aquaria and on the reef flat over a brief period of less than $1 \mathrm{wk}$. Ova and sperm clusters were released simultaneously intermingled in compact buoyant spheres (Fig, 1a, b; Fig. 2) and began to separate within a few minutes to an hour after reaching the surface (Fig. 3). Eggs averaged $394 \mu \mathrm{m}$ (range 363 to $424 \mu \mathrm{m}, \mathrm{N}=21$ ) and $421 \mu \mathrm{m}$ (391 to $440 \mu \mathrm{m}, \mathrm{N}=20$ ) and spheres 3 to 4 and 2 to $3 \mathrm{~mm}$ in diameter in Favites abdita and Leptoria phrygia respectively.

Colonies of Favites abdita released pink eggs and white sperm clusters in aquaria in mid-November during the last quarter lunar phase at approximately 20.00 h during low neap tide. Samples from tagged and untagged colonies on the reef flat confirmed that spawning coincided with that in aquaria. Timing of reproduction in tagged colonies did not differ from untagged control colonies.

Gamete release occurred twice in Leptoria phrygia held in aquaria. The first time, brown-pink eggs were prematurely aborted on 13 November (last quarter moon; 12 November). No sperm were released. Samples chiseled from colonies in the field shortly after this date contained eggs and sperm. The second time, spheres of red eggs and white sperm clusters were released between 9 and 12 December (last quarter moon; 11 December) at approximately $22.00 \mathrm{~h}$; tagged and untagged reef flat colonies sampled on 7 and 14 December had spawned in the interval. The premature spawning in November was probably triggered by placing colonies in aquaria during the lunar phase on which spawning occurs

The eggs of both species remained buoyant and were sticky, adhering to the sides of aquaria and subsequently degenerating within $24 \mathrm{~h}$ of release. Zooxanthellae were not present in the eggs of either species (Fig. 2).

Leptoria phrygia was present in only 2 of the 5 transects providing $0.6 \%$ of the live coral cover. Favites abdita, $F$. halicora and $F$. fexulosa were lumped together since they were difficult to identify in the field. This group formed $1.3 \%$ of live coral cover and was present in all of the 5 transects.

\section{DISCUSSION}

Sexual reproduction by gamete release is similar in all species of Faviidae studied thus far on the Great Barrier Reef (Marshall and Stephenson, 1933; Kojis and Quinn, 1981). Similar reproductive patterns are found in faviids in other parts of the world, but information is limited (Table 1).

Faviid species studied to date are uniformly hermaphroditic with ovary and testis intermingled in the same mesentery. Although oogenesis precedes spermiogenesis by several months, ovaries and testes mature simultaneously (Table 1). Gonads develop as local thickenings of the mesentery in contrast to the gonads of Pocilloporidae which are connected by a short stalk to the mesenteries and project into the body cavity (Rinkevich and Loya, 1979a).

While gonad development follows a similar pattern, different species may either brood larvae or spawn 


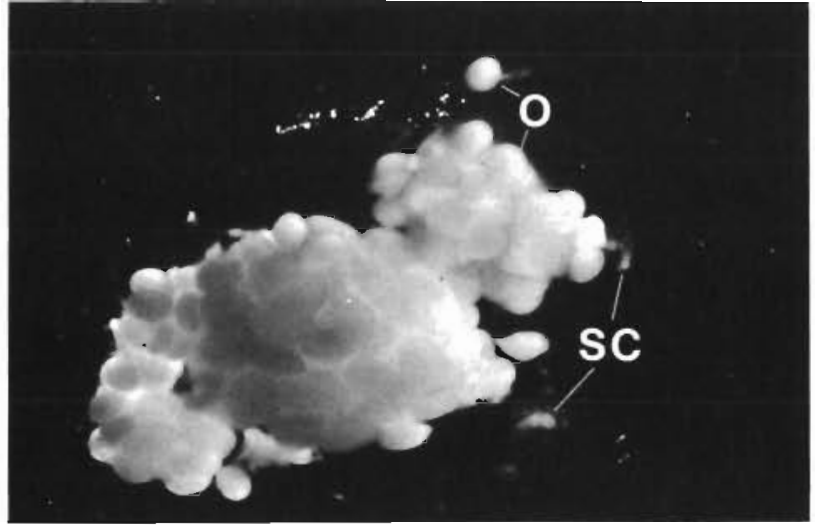

Fig. 3. Favites abdita. Single sphere breaking up on surface of aquaria; ova are separating and sperm clusters rupturing. O ova; SC sperm cluster

eggs and sperm (Table 1). Brooding species have a larval release period from several months (Favia fragum; Lewis 1974) to year-round (Cyphastrea ocellina; Stimson, 1978). Species that spawn, release gametes simultaneously only over several days. The brief spawning period in tropical Faviidae contrasts with the extended spawning period of Scleractinia in temperate climates, i.e. Astrangia danae (Szmant-Froelich et al., 1980), A. lajollaensis and Paracyathus stearnsii (Fadlallah, 1981).
Among Favites abdita, Leptoria phrygia and Goniastrea cf. favulus both cross-fertilization and selffertilization are promoted by the mode and timing of spawning. Populations of all 3 exhibit synchronous spawning, increasing the chances of cross-fertilization where colonies are numerous. However, when colonies are isolated from other conspecifics, self-fertilization of ova may occur. Eggs of $G$. cf. favulus were successfully self-fertilized when colonies were isolated in aquaria and developed into planulae which later settled (Kojis and Quinn, 1981).

Among faviids, the mode and timing of reproduction varies between species and may be related to habitat differences. Species able to live in a wide range of habitats on the reef may have a dispersive mode of reproduction while those occupying a relatively narrow range of habitats may have a means of retaining propagules in the parental habitat.

Of the 3 species of Faviidae studied on Heron Island reef, only Goniastrea cf. favulus is primarily a shallow water species (Kojis and Quinn, 1981). Leptoria phrygia and Favites abdita, while present in shallow water, have a wider local distribution being also present on the reef slope. While all species spawned eggs and sperm, the mode and timing of spawning and the location in the water column of initial larval development differed among them.

Table 1. Pattern of gonad development among species of Faviidae

\begin{tabular}{|c|c|c|c|c|c|c|c|c|c|}
\hline $\begin{array}{l}\text { location } \\
\text { Species }\end{array}$ & Source & 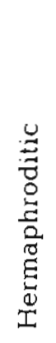 & 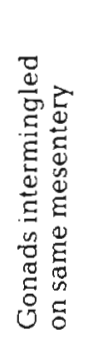 & 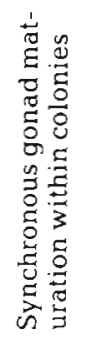 & 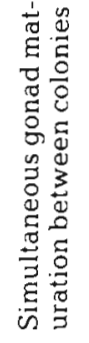 & 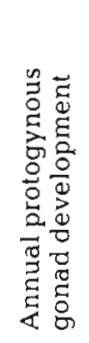 & 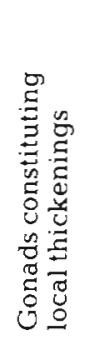 & 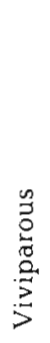 & 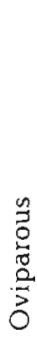 \\
\hline \multicolumn{10}{|l|}{ The Great Barrier Reef } \\
\hline Favia pallida & Marshall \& Stephenson (1933) & $x$ & $x$ & $x$ & $x$ & $x$ & $x$ & & $x$ \\
\hline Favites abdita & & $x$ & $x$ & $x$ & $x$ & $x$ & $x$ & & $x$ \\
\hline $\begin{array}{l}\text { Goniastrea cf. favulus } \\
\text { (= australensis) }\end{array}$ & Koils \& Quinn (1981) & $x$ & $\times$ & $x$ & $x$ & $x$ & $x$ & & $x$ \\
\hline Leptoria phrygia & nots $\alpha$ Qum $(1901)$ & $\hat{x}$ & $x$ & $\hat{x}$ & $x$ & $x$ & $x$ & & $x$ \\
\hline \multicolumn{10}{|l|}{ Red Sea } \\
\hline Favia tavus & Rinkevich \& Loya (1979a) & $x$ & & & & & $x$ & & $x$ \\
\hline Favites abdita & Rinkevich \& Loya (1979a) & $x$ & & & & & $x$ & & \\
\hline Platygyra lamellina & Rinkevich \& Loya (1979a) & $x$ & & & & & $x$ & & \\
\hline \multicolumn{10}{|l|}{ Caribbean } \\
\hline Favia fragum & Duerden (1902) & $x$ & & $x$ & & & & $x$ & \\
\hline Manicina areolata & Vilson (cited in Duerden, 1902) & $x$ & & $x$ & & & & $x$ & \\
\hline \multicolumn{10}{|l|}{ Hawai } \\
\hline Cyphastrea ocellina & Stimson (1978) & & & & & & & $x$ & \\
\hline
\end{tabular}


The manner of spawning of Goniastrea cf. favulus and subsequent larval development facilitated retention of propagules in the habitat in which the adult achieved sexual maturity - the reef flat. Heron Island reef has a tidal range of $>3 \mathrm{~m}$, resulting in a strong current velocity during spring tides. Thus, the combination of at least 3 attributes increases the possibility that the propagules are retained on the reef flat: (1) The precise timing of gonad release to coincide with neap low tide: (2) the nature of the egg masses, which are sticky and demersal; (3) the pattern of larval development (Kojis and Quinn, 1981).

Conversely, Favites abdita and Leptoria phrygia, present in both shallow and deep water habitats, release buoyant gonadal spheres. The spheres and subsequently buoyant eggs may be easily transported. Spawning on the neap tide decreases the probability of long distance dispersal and may be an adaptation to retain propagules in the vicinity of the home reef rather than within the narrow region of the parental habitat.

A brief gamete release period occurs in other reef building corals. A brief spawning period has been observed in species of Acropora (Bothwell, 1981), Faviidae (Rinkevich and Loya, 1979a) and Porites (Kojis and Quinn, 1982). Also, coral spatfall appears to be distinctly seasonal on the Great Barrier Reef occurring primarily during the spring/summer months (Wallace and Bull, 1981).

In summary, we suggest that a brief annual gamete release period with larval development occurring external to the parent colony may be the dominant mode of sexual reproduction among hermatypic corals. However, differences in the timing and manner of gamete release may affect the local distribution and abundance of species.

Acknowledgements. This research was supported by grants from the University of Queensland, The Great Barrier Reef Marine Park Authority and the Ecological Society of Australia. We would like to thank Professor M. Pichon of James Cook University for identifying specimens. Mss. V. Harriot, L. Keyes, I. Stejskal and many others kindly assisted with the field work. The use of Heron Island Research Station facilities is gratefully acknowledged

\section{LITERATURE CITED}

Bothwell, A. M. (1981). Fragmęntation, a means of asexual reproduction and dispersal in the genus Acropora. Abstracts of papers, 4 th International Coral Reef Symposium, Manila, Philippines, pp. 7-8

Connell, J. H. (1973). Population ecology of reef-building corals. In: Jones, O. A., Endean, R. (eds.) Biology and geology of coral reefs, Vol. 2. Academic Press, New York, pp. 205-245

Duerden, J. E. (1902). West Indian Madreporarian polyps. Mem. natn. Acad. Sci. 8: 402-597

Fadlallah, Y. H. (1981). The reproductive biology of three species of corals from central California. Ph. D. thesis, University of California at Santa Cruz

Kojis, B. L., Quinn, N. J. (1981). Aspects of sexual reproduction and larval development in the shallow water hermatypic coral, Goniastrea australensis (Edwards and Haime, 1857). Bull. mar. Sci. 31: 558-573

Kojis, B. L., Quinn, N. J. (1982). Reproductive strategies in four species of Porites (Scleractinia). Proceedings of the 4th International Coral Reef Symposium, Manila, Philippines (in press)

Lewis, J. B. (1974). The settlement behaviour of planulae larvae of the hermatypic coral Favia fragum (Esper). J. exp. mar. Biol. Ecol. 15: 165-172

Marshall, S. M., Stephenson, T. A. (1933). The breeding of reef animals, Part 1, The corals. Scient. Rep. Gt Barrier Reef Exped. 3: 219-245

Rinkevich, B., Loya, Y. (1979a). The reproduction of the Red Sea coral Stylophora pistillata. I. Gonads and planulae. Mar. Ecol. Prog. Ser. 1: 133-144

Rinkevich, B., Loya, Y. (1979b). The reproduction of the Red Sea coral Stylophora pistillata. II. Synchronization in breeding and seasonality of planulae shedding. Mar. Ecol. Prog. Ser. 1: 145-152

Stimson, J. S. (1978). Mode and timing of reproduction in some common hermatypic corals of Hawaii and Enewetak. Mar. Biol. 48: 173-184

Szmant-Froelich, A., Yevich, P., Pilson, M. E. Q. (1980). Gametogenesis and early development of the temperate coral Astrangia danae (Anthozoa: Scleractinia). Biol. Bull. mar. biol. Lab., Woods Hole 158: 257-269

Veron, J. E. N., Pichon, M., Wijsman-Best, M. (1977). Scleractinia of eastern Australia. Part II. Families Faviidae, Trachyphylliidae. Monograph Ser. Aust. Inst. Mar. Sci. 3: $1-233$

Wallace, C. C., Bull, G. D. (1981), Patterns of juvenile coral recruitment on a reef front during a spring-summer spawning period. Abstracts of papers, 4th International Coral Reef Symposium, Manila, Philippines, p. 71 